\title{
Analysis of the effect of supplier-company's long-term commitment, communication and strategy on supply chain performance in manufacturing sector
}

\author{
Mulyaningsih $^{\mathrm{a}^{*}}$, Tinneke Hermina ${ }^{\mathrm{a}}$, Gugun Geusan Akbar ${ }^{\mathrm{a}}$, Aceng Ulumudin ${ }^{\mathrm{a}}$
}

${ }^{a}$ Universitas Garut, Indonesia

\section{H R O N I C L E}

Article history:

Received April 6, 2021

Received in revised format May

16, 2021

Accepted June 102021

Available online

June 182021

Keywords:

Commitment

Communication

Long-Term Cooperation Strategy

Supply Chain Performance

\begin{abstract}
A B S T R A C T
The purpose of this study is to find answers to the research problem posed, namely the implementation of the long-term cooperation strategy between suppliers and companies through supplier commitment factors with companies and supplier communication with companies that can improve the company's supply chain performance. The populations in this study are suppliers of manufacturing companies listed on the Indonesia Stock Exchange (BEI) in 2016-2020. Data were collected using a questionnaire containing questions related to research. Furthermore, in this study a theoretical model was developed by proposing 5 hypotheses to be tested using Structural Equations Modeling (SEM) using AMOS software. The results showed that the function and existence of the antecedents of the Long-Term Cooperation Strategy have a high role in determining Supply Chain Performance. Based on the influence analysis, it can be concluded that Communication has a higher influence on Supply Chain Performance compared to Commitment.
\end{abstract}

\section{Introduction}

Very tight competition requires business managers to create new models in managing product and information flows. Heizer and Render (2013) explain that the important role of all parties, from suppliers, manufacturers, distributors, retailers and customers in creating cheap, quality and fast products, has given birth to a new concept, namely Supply Chain Management (SCM). SCM (supply chain management) is an extension and development of the concept of logistics management (He et al., 2014). A supply chain management system involves the process of producing, shipping, storing, distributing, and selling a product to meet the demand for that product. The supply chain in it includes all processes and activities involved in delivering these products to consumers (Stadtler et al., 2015). Venus (2014) argues that the supply chain must have good performance to optimize profits in every part of the supply chain. Supply chain performance needs to be maintained by periodically improving supply chain performance, especially if changes are made to the supply chain structure. The concept of supply chain management itself has been further expanded with a relationship management approach and a stronger collaboration between the various stages of the supply chain is needed (Vogt, 2011). Strategic partnerships emphasize long-term, direct relationships that support the planning process and problem-solving efforts (Shiraz \& Ramezani, 2014) which enable companies to work more effectively with suppliers who have the willingness to share responsibility for ensuring product success. Thatte et al. (2013) show the strategic advantages of cooperative relationships from various industries, and Zhu et al. (2014) uses this cooperative relationship as one of the key factors to add value to the company in his analysis of business strategy. Quality collaborative relationships are increasingly taking center stage in the analysis of how firms compete. According to Morgan and Hunt (1994) commitment is a motivation to maintain and extend relationships. Matin et al. (2010) states that the relationship depends on a mutually beneficial commitment between the buyer and the seller. When the motivation to maintain the relationship is high, then there is a possibility that the relationship commitment is also high. The * Corresponding author

E-mail address: mulyaningsih10.uniga@gmail.com (Mulyaningsih)

(C) 2021 Growing Science Ltd. All rights reserved.

doi: $10.5267 /$ j.uscm.2021.6.011 
long-lasting relationship shows a certain degree of commitment between the buyer-seller (Plenert, 2014). Alhaji (2012) found that communication is an important key for the continuation of a collaborative relationship. Communication is seen as the most important element for the success of relationships between companies because the fact proves that relationships between companies always involve communication. Thus, good communication should be one of the factors that determine the success of cooperation between companies (Nawab \& Bhatti, 2017).

Suppliers are one of the factors of an important raw material distribution channel for the company. Suppliers chosen by companies that are not well managed allow suppliers to be late in procuring raw materials for the company, because it can reduce the performance of suppliers and there is no transparency in bargaining prices between suppliers and companies (Neutzling et al., 2018). Also added by Karimi \& Rafiee (2014), delays in raw materials can affect operations at the company. The importance of the existence of suppliers for the company makes the company must be able to manage and choose the relationship with its suppliers. The application of SCM following the correct concept can have an impact on increasing competitive advantage on products and on the supply chain system built in the company (Arvitrida et al., 2017). The results of research by Morgan and Hunt (1994) show that commitment between suppliers and companies has an influence on longterm cooperation strategies, while Anderson and Weitz's (1992) research shows that commitment between suppliers and retail companies has a low effect on long-term cooperation strategies. The research results of Gimenez et al. (2012) show that the cooperation strategy between suppliers and companies has an influence on supply chain performance. Meanwhile, research by de Souza Miguel abd Brito (2011), which examined supply chain performance, did not find a significant relationship between long-term cooperation strategies and supply chain performance. In meeting raw material needs, manufacturing companies establish long-term cooperation with many suppliers. But there are obstacles in cooperation between suppliers of raw materials and companies, namely delays in the supply of raw materials and inaccuracies in fulfilling raw material supply contracts. This can cause problems in meeting the company's production quota. Many of the suppliers of raw materials for manufacturing companies only think about short-term relationships without thinking about the long-term sustainability of the relationship.

\section{Literature Review and Hypothesis}

\subsection{Managerial Commitment and Communication}

According to Morgan and Hunt (1994), commitment is defined as trust in a cooperative relationship that occurs in a continuous relationship which is very important as a guarantee of efforts to maintain the cooperation they do. Further explained by Fredberg et al. (2008) that commitment is the ability to develop good relationship exchanges and illustrates the highest level of relational bonding, commitment also includes activities to maintain a relationship. Relationships occur if the company can provide high commitment to its customers, of course, it will provide high satisfaction and trust in its customers, because commitment is generally seen as a strength of the relationship between the company and customers (Yahaya \& Ebrahim, 2016). In establishing long-term relationships between companies, what companies need to affirm is to maintain commitment and trust (Khan \& Rashid, 2012). The conclusion of the definition of commitment in the relationship between companies is an attitude that the company takes so that the relationship is meaningful and stable (Gallato et al., 2012). Through a commitment to maintaining long-term relationships between companies, it is hoped that the development and benefits of this relationship can be achieved. Mohr et al. (1996) define communication as a reciprocal relationship that is structured, planned and routine between companies and suppliers. Meanwhile, according to Johlke and Duhan (2001) communication is a process used to exchange information and influence from one party to another. Some researchers place communication as an important element in collaborating with other parties (Miller, 2009). According to Papa et al. (2007), there are four main dimensions of channel communication, namely the size of the communication, the content of the communication, the communication media and the communication feedback. The amount of communication can be measured by the frequency and duration of contact. The amount of contact must be compared with the number required to carry out the activity. Research measuring frequency recognizes that there is an optimal level of communication, where too much or too little communication can have a negative influence on the effectiveness of communication. Relationship communication shows the company as an individual feels the added value of the relationship that exists between them, which illustrates the closeness between the two companies. High relationship communication will lead to interactions and relationships between the companies concerned, which in turn can be seen as a strategic asset. The company tries to optimize this strategic potential from good relationship communication (Griffin, 2006). Morgan \& Hunt (1994) observed that willingness to share information in a timely, meaningful manner is important when choosing a partner, because communication is an important part of resolving disagreements. Therefore, communication is likened to glue or glue that strengthens relationships between companies. Communication plays an important role for the success of relationships between companies. Many problems in relationships between companies are successfully resolved through good communication (Modaff et al., 2016).

\subsection{Long-term Cooperation Strategy and Supply Chain Performance}

The growing flow of globalization, rapid technological developments, and unpredictable economic situations are factors that encourage the emergence of a concept of long-term collaborative relationships between suppliers and companies. Long-term collaborative relationships can be realized through processes and products, increasing conformity with one another, sharing 
information and reducing sources of uncertainty (Chan, 2003). Liew (2008) argues that long-term relationships are a perception of the interdependence of companies and suppliers both in the context of products and relationships and it is hoped that interdependence will be of value to the company in the long run. This dependency value will make them try to build each other and maintain the valuable attributes in their cooperative relationship. Tungjitjarurn et al. (2012) stated that the main dimensions that characterize successful supplier development will include, but are not limited to integrating and improving activities and processes, continuous collaboration and mutually beneficial long-term relationships as a result of improvement efforts and a clear structure for both companies are concerned with costs, prices and profits. The relationship between suppliers, customers and companies must be well managed and always improved so that a sustainable relationship is established and suppliers are responsible for product quality and so that the distribution of products from upstream to downstream is timely for the end users (Guney \& Fairchild, 2011). In principle, the ultimate goal to be achieved in managing long-term relationships is the profitability of the company obtained through continuous and mutually beneficial relationships so as to create consistent and sustainable long-term relationships (Chenet et al., 2010).

According to Anatan (2008) supply chain performance is a measure of product quality, delivery performance, and price, responsiveness to demand changes, service support, and overall performance. Chopra \& Meindl (2007) say that measuring performance is complex and a big challenge for a researcher. Performance is a big challenge because as a construct, performance is multidimensional so that the use of a single measurement is not able to provide a comprehensive understanding (Pujawan \& Mahendrawathi, 2010). The relationship with the end customer is a must in achieving success in the supply chain. Supply chains must be close to their end consumers to form cooperative relationships in demand planning (Marhamati et al., 2017). While companies compete through product customization, high quality, cost reduction and speed of reaching the market, additional emphasis is placed on the supply chain. The thinking that underlies supply chain management is focusing on reducing waste and maximizing the supply chain (Indrajit \& Djokopranoto, 2002). Supply chain performance is a factor commonly used to measure the impact of the strategy implemented by the organization. In other words, supply chain performance is a concept for assessing the performance of business activities carried out by organizations related to effective distribution processes ( $\mathrm{Lu}, 2011)$.

Based on the theoretical description, the hypotheses used in this study are as following:

$\mathrm{H}_{1}$ : Managerial commitment has a positive effect on long-term cooperation strategies.
$\mathrm{H}_{2}$ : Managerial commitment has a positive effect on long-term cooperation strategies.
$\mathrm{H}_{3}$ : Managerial commitment has a positive effect on supply chain performance.
$\mathrm{H}_{4}$ : Managerial commitment has a positive effect on supply chain performance.
$\mathrm{H}_{5}$ : The long-term cooperation strategy has a positive effect on supply chain performance.

\section{Research Methods}

In this study presents a causal relationship which is a determination on the level of influence that can also be used to make predictions. Researchers can identify these facts or events as the affected variable (dependent variable) and conduct research on the influencing variable (independent variable). The variables in this study consist of Commitment, Communication, LongTerm Cooperation Strategy and Supply Chain Performance. This study uses primary data obtained in the field. The primary data in this research are respondents' answers about the analysis of the supply chain performance of manufacturing companies. Data were collected using a prepared questionnaire. Secondary data used in this study are data on the fulfillment of raw material supply contracts and data on delays in the supply of raw materials. The questionnaire used in this study contains two main parts. The first part is about the respondent's social profile, containing the respondent's data related to the respondent's identity. While the second part concerns the factors that affect supply chain performance. Population is a generalization area consisting of objects or subjects that have certain qualities and characteristics that are determined by the researcher for study and then draw conclusions (Mas'ud, 2004). The populations in this study are partners (suppliers of raw materials) of manufacturing companies listed on the IDX for the 2016-2020 periods. The sample is the source of the population, consisting of several members of the population. This subset is taken because in many cases it is impossible to study all members of the population, therefore we form a population representative called the sample (Ferdinand, 2006). In this questionnaire as many as 250 questionnaires were circulated. The sampling technique used in this study is a census, where all available populations are sampled to obtain information in accordance with predetermined criteria, namely suppliers of raw materials for manufacturing companies. Data collection techniques can be done by interview, questionnaire, observation and a combination of the three (Sugiyono, 2002). The sampling technique used in this study was a census, using a questionnaire. The questionnaire is a data collection technique that is carried out by giving a set of questions or written statements to the respondent to answer (Sugiyono, 2002). The questionnaire gives the respondent the responsibility to read and answer questions (Indriantoro \& Supomo, 2002). The list of questions asked of respondents to get data about the variables measured in this study. Questions in a closed questionnaire are made with an ordinary scale, which is used to measure the attitudes, opinions and perceptions of a person or group of people about social phenomena (Sugiyono, 2002). Reliability test is used that aims to find out how reliable or trustworthy a measuring instrument is. Reliability relates to estimating the extent to which a measuring instrument is seen from the stability or internal consistency of the answers/questions if observations are made repeatedly. If a measuring instrument is used repeatedly and the measurement results obtained are relatively consistent, then the measuring 
instrument is considered reliable and reliable. Furthermore, validity is defined as a measure of the accuracy of a test instrument to perform its measuring function (Indriantoro \& Supomo, 2002). The higher the reliable validity of a measuring instrument will hit its target or provide measurement results in accordance with the purpose of the measurement. The validity test is carried out by calculating the correlation between the variables making up the variables with the variable total score to determine the relationship between variables and the variable total score. In this study, the reliability and validity test used the Pearson correlation method found in the SPSS software.

In this study, the analysis technique used is Structural Equations Modeling (SEM) which is operated through the AMOS program. According to Ferdinand (2006), research modeling through SEM allows a researcher to answer research questions that are both regressive and dimensional (i.e. measuring what the dimensions of a concept are). SEM can also identify the dimensions of a concept or construct and at the same time SEM can also measure the influence or degree of factor relationship to which the dimensions will be identified. The reason for using SEM is because in SEM, exogenous and endogenous confirmatory construct testing is carried out, where the exogenous confirmatory construct test is to test the feasibility of the model between the independent variable and the intervening variable, while the endogenous confirmatory construct test is to test the feasibility of the model between the intervening variable and the dependent variable. This is done in order to get good research results. The advantages of SEM applications in management research are due to its ability to confirm the dimensions of a concept or factor that is very commonly used in management and its ability to measure the effect of theoretical relationships (Hair et al., 2010).

\section{Results}

Respondents in this research were as many as 250 suppliers of raw materials for manufacturing companies listed on the Indonesia Stock Exchange (IDX) in 2016-2020, but the data that was ultimately used in the analysis were 209 questionnaires. This was caused by 31 questionnaires that did not return and 10 questionnaires that were not filled in completely (missing data). This study uses questionnaire data as primary data, so a question-testing step is needed to determine whether the question is feasible or not. To find out whether the question is feasible or not, the validity test is used. This test is used to measure the feasibility and validity of a question item. The decision criterion is to compare the value of Corrected Item - Total Correlation compared to the value of $r$ table with a level $(\alpha)$ of 0.05 . The decision criteria, if the value of Corrected Item - Total Correlation is greater than $r$ table, then the indicator is feasible (valid) and vice versa (Ghozali, 2016). Meanwhile, another instrument test is the reliability test, which is related to the problem of the accuracy of the data, for reliability testing through the alpha coefficient value compared to the value of 0.60. A construct or variable is said to be reliable if it has an alpha value above 0.60 or preferably (Ghozali, 2016). Based on the results of calculations with the SPSS program, the validity and reliability test can be presented in Table 1 below:

Table 1

Results of Testing the Reliability and Validity of the Questionnaire Instruments

\begin{tabular}{|c|c|c|c|}
\hline Constructs/Latent Variables & Reliability (Cronbach $\alpha$ ) & Item (Indicator) & Corrected Item - Total Correlation \\
\hline \multirow[t]{4}{*}{ Commitment } & 0.879 & $\mathrm{X} 11$ & 0.742 \\
\hline & & $\mathrm{X} 12$ & 0.780 \\
\hline & & $\mathrm{X} 13$ & 0.777 \\
\hline & & $\mathrm{X} 14$ & 0.671 \\
\hline \multirow[t]{4}{*}{ Communication } & 0.939 & $\mathrm{X} 21$ & 0.911 \\
\hline & & $\mathrm{X} 22$ & 0.855 \\
\hline & & $\mathrm{X} 23$ & 0.845 \\
\hline & & $\mathrm{X} 24$ & 0.830 \\
\hline \multirow[t]{4}{*}{ Long-term Cooperation Strategy } & 0.929 & Y11 & 0.870 \\
\hline & & Y12 & 0.876 \\
\hline & & Y13 & 0.859 \\
\hline & & Y14 & 0.753 \\
\hline \multirow[t]{4}{*}{ Supply Chain Performance } & 0.925 & Y21 & 0.820 \\
\hline & & Y22 & 0.893 \\
\hline & & Y23 & 0.811 \\
\hline & & Y24 & 0.860 \\
\hline
\end{tabular}

Based on Table 1, it can be shown that all (observed) indicators are valid, this is indicated by the value of Corrected Item Total Correlation $>\mathrm{r}$ table. This evidence shows that all (observed) indicators are suitable to be used as indicators of the construct (variable latency). The alpha coefficient (Cronbach alpha) has a value above 0.60 so it can be explained that the research variables (constructs) in the form of commitment variables, relationship communication, long-term cooperation strategies and supply chain performance are reliable or have high reliability, so that it has the accuracy to be used as a variable (construct) in a study. In this last stage, model interpretation is carried out and modifies the model that does not meet the test requirements. After the model is estimated, the residual must be small or close to zero and the frequency distribution of the covariance produced by the model, then a residual modality must be symmetrical. The safety limit for the residual amount is $5 \%$. If the residual amount is greater than $5 \%$ of all covariance residuals produced by the model, then a modification needs to be considered provided there is a theoretical basis. Furthermore, if it is found that the residual value generated by the model is quite large ( $>2.58)$, another way to modify it is to consider adding a new flow to the estimated model. The cut off value of 
\pm 2.58 can be used to assess the significance of the residuals generated by the model. Standardized residual covariances data processed by the AMOS program can be seen in Table 2 below:

Table 2

Standardized Residual Covariances (Group number 1 - Default model)

\begin{tabular}{|c|c|c|c|c|c|c|c|c|c|c|c|c|c|c|c|c|}
\hline & Y21 & Y22 & Y23 & Y24 & Y11 & $\mathrm{Y12}$ & Y13 & $\mathrm{Y14}$ & K21 & K22 & K23 & K24 & X11 & $\mathrm{X12}$ & $\mathrm{X13}$ & $\mathrm{X14}$ \\
\hline Y21 & 0.000 & & & & & & & & & & & & & & & \\
\hline Y22 & -0.134 & 0.000 & & & & & & & & & & & & & & \\
\hline Y23 & 0.026 & -0.001 & 0.000 & & & & & & & & & & & & & \\
\hline Y24 & -0.166 & 0.034 & 0.472 & 0.000 & & & & & & & & & & & & \\
\hline Y11 & -0.013 & 0.034 & -0.213 & -0.216 & 0.000 & & & & & & & & & & & \\
\hline Y12 & 0.088 & 0.032 & -0.143 & 0.046 & -0.075 & 0.000 & & & & & & & & & & \\
\hline Y13 & 0.084 & 0.0123 & -0.002 & 0.081 & 0.019 & -0.017 & 0.000 & & & & & & & & & \\
\hline Y14 & -0.051 & 0.042 & -0.089 & -0165 & -0.066 & 0049 & 0.48 & 0.000 & & & & & & & & \\
\hline K21 & 0.005 & 0.077 & -0.053 & -0195 & -0.133 & 0.025 & -0.078 & $-0 .-29$ & 0.000 & & & & & & & \\
\hline K22 & 0.153 & 0.027 & -0.127 & 0.078 & 0.077 & 0.009 & 0.003 & 0.039 & -0.015 & 0.000 & & & & & & \\
\hline K23 & 0.111 & 0.003 & -0.211 & -0.126 & 0.264 & 0.128 & -0.114 & -0.092 & 0.059 & 0.018 & 0.000 & & & & & \\
\hline K24 & 0.042 & 0.019 & 0.002 & -0.191 & 0.081 & -0.025 & -0.031 & -0.042 & 0.035 & -0.072 & 0.001 & 0.000 & & & & \\
\hline X11 & 0.034 & -0.069 & -0.169 & 0.087 & 0.148 & 0.089 & -0.065 & -0.024 & 0.083 & 0.085 & 0.013 & 0.059 & 0.000 & & & \\
\hline X12 & 0.081 & 0.005 & -0.187 & -0.106 & 0.0139 & -0.134 & 0.004 & 0.069 & -0.079 & -0.12 & -0.154 & 0.079 & 0.064 & 0.000 & & \\
\hline $\mathrm{X} 13$ & 0.121 & 0.078 & -0.173 & -0.173 & -0.112 & 0.012 & -0.003 & 0.076 & -0.011 & -0.039 & -0.167 & 0.019 & -0.087 & 0.063 & 0.000 & \\
\hline X14 & 0.141 & $0 . .069$ & 0.157 & -0.007 & 0.006 & -0.006 & -0.149 & 0.006 & 0.121 & -0.009 & 0.091 & 0.108 & -0.177 & -0.061 & 0.121 & 0.000 \\
\hline
\end{tabular}

Table 2 shows that none of the standardized residual covariance values are greater than 2.58 . Thus, the model does not require significant modification.

Table 3

Reliability Test Results and Variance Extract

\begin{tabular}{|c|c|c|c|c|c|c|c|c|}
\hline Variable & & Loading & Loading2 & Error & 1-Error & 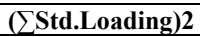 & Reliable & Var. Ext \\
\hline \multirow[t]{5}{*}{ Commitment } & $\mathrm{X} 11$ & 0.915 & 0.838 & 0.838 & 0.158 & \multirow[t]{5}{*}{13.861} & \multirow[t]{5}{*}{0.959} & \multirow[t]{5}{*}{0.798} \\
\hline & $\mathrm{X} 12$ & 0.934 & 0.874 & 0.874 & 0.119 & & & \\
\hline & $\mathrm{X} 13$ & 0.954 & 0.912 & 0.912 & 0.091 & & & \\
\hline & $\mathrm{X} 14$ & 0.925 & 0.857 & 0.857 & 0.139 & & & \\
\hline & Total & 3.734 & 3.487 & 3.487 & 0.509 & & & \\
\hline \multirow[t]{5}{*}{ Communication } & X21 & 0.947 & 0.889 & 0.889 & 0.102 & \multirow[t]{5}{*}{14.589} & \multirow[t]{5}{*}{0.956} & \multirow[t]{5}{*}{0.789} \\
\hline & $\mathrm{X} 22$ & 0.961 & 0.925 & 0.925 & 0.069 & & & \\
\hline & $\mathrm{X} 23$ & 0.945 & 0.896 & 0.896 & 0.098 & & & \\
\hline & $\mathrm{X} 24$ & 0.946 & 0.896 & 0.896 & 0.098 & & & \\
\hline & Total & 3.805 & 3.622 & 3.622 & 0.381 & & & \\
\hline \multirow{5}{*}{$\begin{array}{l}\text { Long-term } \\
\text { Cooperation } \\
\text { Strategy }\end{array}$} & Y11 & 0.928 & 0.863 & 0.863 & 0.129 & \multirow[t]{5}{*}{14.202} & \multirow[t]{5}{*}{0.971} & \multirow[t]{5}{*}{0.787} \\
\hline & Y12 & 0.938 & 0.881 & 0.881 & 0.121 & & & \\
\hline & Y13 & 0.956 & 0.916 & 0.916 & 0.079 & & & \\
\hline & Y14 & 0.937 & 0.880 & 0.880 & 0.108 & & & \\
\hline & Total & 3.765 & 3.546 & 3.546 & 0.509 & & & \\
\hline \multirow{5}{*}{$\begin{array}{l}\text { Supply Chain } \\
\text { Performance }\end{array}$} & Y21 & 0.942 & 0.889 & 0.889 & 0.112 & \multirow[t]{5}{*}{13.499} & \multirow[t]{5}{*}{0.962} & \multirow[t]{5}{*}{0.786} \\
\hline & Y22 & 0.921 & 0.850 & 0.850 & 0.151 & & & \\
\hline & Y23 & 0.912 & 0.834 & 0.834 & 0.158 & & & \\
\hline & Y24 & 0.892 & 0.797 & 0.797 & 0.199 & & & \\
\hline & Total & 3.673 & 3.376 & 3.376 & 0.618 & & & \\
\hline
\end{tabular}

Table 3 shows that the instrument construct reliability has met the research requirements, namely $\geq 0.7$ as well as the variance extract results that have met the requirements, namely $\geq 0.50$. The results of the SEM Full Model after processing can be seen in Fig. 1.

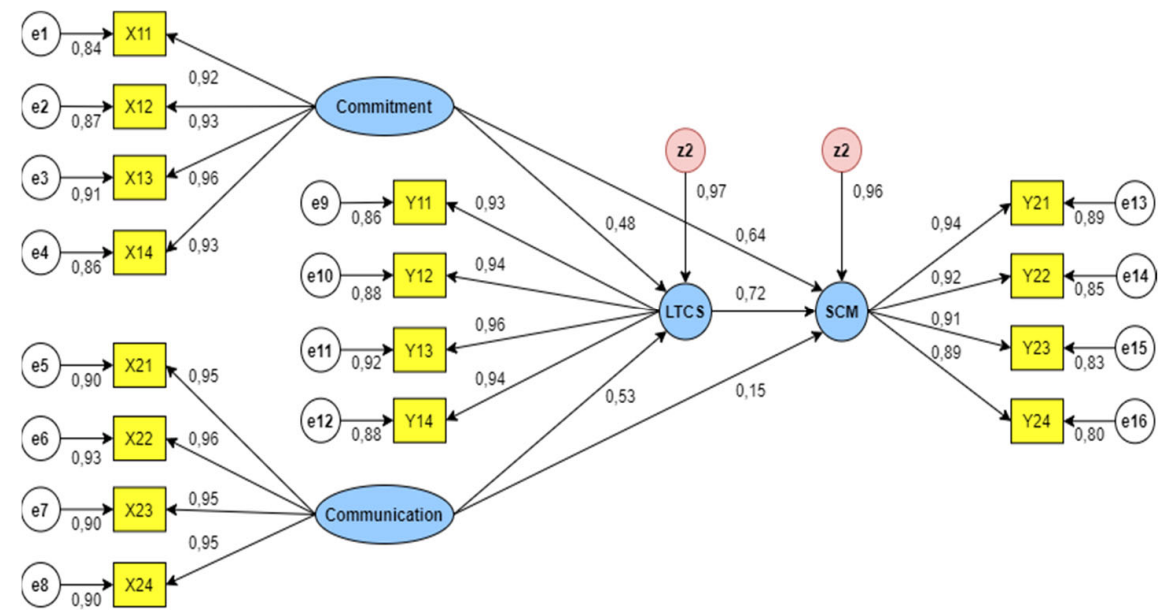

Fig. 1. Full Model Confirmatory Analysis 
Table 4

Model Feasibility Test Results (Full Model)

\begin{tabular}{llll}
\hline Goodness of Fit Index & Cut-off Value & Model Result & Information \\
\hline Chi-Square & $122.11 \mathrm{df}=98$ & 112.197 & Good fit \\
\hline Significant Probability & $\geq 0.05$ & 0.098 & Good fit \\
GFI & $\geq 0.90$ & 0.911 & Good fit \\
RMSEA & $\geq 0.08$ & 0.045 & Good fit \\
AGFI & $\geq 0.90$ & 0.868 & Moderate \\
TLI & $\geq 0.90$ & 0.989 & Good fit \\
NFI & $\geq 0.90$ & 0.971 & Good fit \\
CFI & $\geq 0.90$ & 0.986 & Good fit \\
CMIN/DF & $\geq 2.00$ & 1.201 & Good fit \\
\hline
\end{tabular}

The processing results in the full model factor analysis show that the Goodness of fit index is within the expected value range, except for AGFI (Table 4). However, this value is in a tolerable range. Thus, this test results in confirmation of either or the dimension of the factors as well as the relationship between causality and factors. According to Ghozali (2016), it is not important for a model to be truly fit or even close to good to start building a predictive research or confirm a theory, if a statistical model from the data can be achieved.

\section{Table 5}

Full Model Weight Regression

\begin{tabular}{|c|c|c|c|c|c|c|c|}
\hline Variable & & & Estimate & S.E. & C.R. & $\mathbf{P}$ & Label \\
\hline SKJP & $\leftarrow$ & Commitment & 0.482 & 0.239 & 2.010 & 0.042 & par_13 \\
\hline SKJP & $\leftarrow$ & Communication & 0.525 & 0.248 & 2.106 & 0.033 & par_15 \\
\hline KRP & $\leftarrow$ & Commitment & 0.064 & 0.316 & 0.206 & 0.833 & par_14 \\
\hline KRP & $\leftarrow$ & Communication & 0.146 & 0.319 & 0.459 & 0.643 & par_16 \\
\hline KRP & $\leftarrow$ & SKJP & 0.718 & 0.337 & 2.118 & 0.032 & par_17 \\
\hline Y14 & $\leftarrow$ & SKJP & 1.000 & & & & \\
\hline Y13 & $\leftarrow$ & SKJP & 0.990 & 0.040 & 23.698 & $* * *$ & par_1 \\
\hline Y12 & $\leftarrow$ & SKJP & 1.018 & 0.045 & 21.588 & $* * *$ & par_2 \\
\hline Y11 & $\leftarrow$ & SKJP & 1.186 & 0.051 & 20.658 & $* * *$ & par_3 \\
\hline Y21 & $\leftarrow$ & KRP & 1.000 & & & & \\
\hline Y22 & $\leftarrow$ & KRP & 1.072 & 0.052 & 20.204 & $* * *$ & par_4 \\
\hline Y23 & $\leftarrow$ & KRP & 0.991 & 0.049 & 19.476 & $* * *$ & par_5 \\
\hline Y24 & $\leftarrow$ & KRP & 1.014 & 0.054 & 17.980 & $* * *$ & par_6 \\
\hline $\mathrm{X} 11$ & $\leftarrow$ & Commitment & 1.000 & & & & \\
\hline $\mathrm{X} 12$ & $\leftarrow$ & Commitment & 1.048 & 0.052 & 19.279 & $* * *$ & par_7 \\
\hline $\mathrm{X} 13$ & $\leftarrow$ & Commitment & 1.083 & 0.050 & 20.748 & $* * *$ & par_8 \\
\hline X14 & $\leftarrow$ & Commitment & 0.946 & 0.049 & 18.606 & $* * *$ & par-9 \\
\hline X24 & $\leftarrow$ & Communication & 1.000 & & & & \\
\hline $\mathrm{X} 23$ & $\leftarrow$ & Communication & 1.025 & 0.042 & 23.289 & $* * *$ & par_10 \\
\hline $\mathrm{X} 22$ & $\leftarrow$ & Communication & 1.169 & 0.044 & 25.311 & $* * *$ & par_11 \\
\hline $\mathrm{X} 21$ & $\leftarrow$ & Communication & 1.101 & 0.045 & 23.500 & $* * *$ & par_12 \\
\hline
\end{tabular}

Hypothesis testing is done by comparing the C.R value in Table 5 with the critical value that is identical to the $t$ value, which is 1.654 at the significance level of $p<0.05$, so the proposed hypothesis is accepted. However, if the value of C.R has not been able to reach its critical value at the significance level of $p>0.05$, the proposed hypothesis is rejected. The following is a discussion of each hypothesis test based on the test results summarized in Table 6 .

Table 6

Hypothesis Conclusion

\begin{tabular}{ll}
\hline Hypothesis & Score \\
\hline $\mathbf{H}_{1}:$ Commitment has a positive effect on long-term cooperation strategies & C.R $=2.010 \mathrm{P}=0.042$ \\
$\mathbf{H}_{2}:$ Communication has a positive effect on long-term cooperation strategies & C.R $=2.106 \mathrm{P}=0.033$ \\
$\mathbf{H}_{3}$ : Commitment has a positive effect on supply chain performance & C.R $=0.206 \mathrm{P}=0.833$ \\
$\mathbf{H}_{4}$ : Communication has a positive effect on supply chain performance & C.R $=0.459 \mathrm{P}=0.643$ \\
$\mathbf{H}_{5}:$ The long-term cooperation strategy has a positive effect on supply chain performance & C.R $=2.118 \mathrm{P}=0.032$ \\
\hline
\end{tabular}

Influence analysis needs to be done to determine the magnitude of the influence of exogenous variables on endogenous variables, either directly, indirectly, or totally, as presented in Table 7 below:

Table 7

Direct, Indirect and Total Effects

\begin{tabular}{llll}
\hline Influence & $\begin{array}{l}\text { Commitment to Supply Chain } \\
\text { Performance }\end{array}$ & $\begin{array}{l}\text { Communication on Supply Chain } \\
\text { Performance }\end{array}$ & $\begin{array}{l}\text { Long-term Cooperation Strategy on Supply } \\
\text { Chain Performance }\end{array}$ \\
\hline Live & 0.069 & 0.148 & 0.759 \\
Indirect & 0.369 & 0.391 & 0.000 \\
\hline Total & 0.438 & 0.539 & 0.759 \\
\hline
\end{tabular}


Based on the calculation of the direct and indirect effect of commitment and communication on supply chain performance, which shows one comparison that leads to the direct effect of commitment on supply chain performance is 0.069 ; the indirect effect of commitment to supply chain performance is 0.369 ; whereas the total effect of commitment to supply chain performance is 0.438 . The direct effect of communication on supply chain performance is 0.148 ; the indirect effect of communication on supply chain performance is 0.391 ; while the total effect of communication on supply chain performance is 0.539 . The direct effect of a long-term cooperation strategy on supply chain performance is 0.759 . This shows that the function and existence of the antecedents of the long-term cooperation strategy have a high role in determining supply chain performance. Based on the influence analysis above, it can be shown that communication has a higher effect on improving supply chain performance than commitment.

\section{Conclusion}

Based on the results of statistical analysis testing and the discussion that has been carried out, the following conclusions are obtained. By looking at the communication media factor as an important factor as a success in improving supply chain performance through the implementation of a long-term cooperation strategy, companies in carrying out their business activities must apply appropriate communication media. The results would imply that it needs full support from company management to continue to improve the effectiveness and efficiency of SCM. The improvement was not only related to equipment, but also related to human resources, appropriate allocation of human resources and ongoing and adequate training to continue to support long-term cooperation that will improve supply chain performance. The limitations of this study are that the results of this study cannot be generalized to other cases outside the object of this study and companies in other sectors. Moreover, it is also taking the sample only the manufacturing sector is used. As a suggestion, in further research, a wider sample can be used so that it can better represent the actual situation, as well as to add research variables so that they can provide a more diverse representation for the company and use different analysis software and tools in analyzing data.

\section{References}

Alhaji, I. A. (2012). Does motivational factor influence organizational commitment and effectiveness? A review of literature. E3 Journal of Business Management and Economics., 3(1), 001-009.

Anatan, L. (2008). Supply Chain Management. Teori dan Aplikasi.

Anderson, E., \& Weitz, B. (1992). The use of pledges to build and sustain commitment in distribution channels. Journal of Marketing Research, 29(1), 18-34.

Arvitrida, N., Tako, A., Robertson, D., \& Robinson, S. (2017). Duration of collaboration from a market perspective: An agentbased modeling approach. Operations and Supply Chain Management: An International Journal, 10(3), 149-159.

Chan, S. (2003). Relationship marketing: inovasi pemasaran yang membuat pelanggan bertekuk lutut. Gramedia Pustaka Utama.

Chenet, P., Dagger, T. S., \& O'Sullivan, D. (2010). Service quality, trust, commitment and service differentiation in business relationships. Journal of services Marketing, 24(5).

Chopra, S., \& Meindl, P. (2007). Supply chain management. Strategy, planning \& operation. In Das summa summarum des management (pp. 265-275). Gabler.

de Souza Miguel, P. L., \& Brito, L. A. L. (2011). Supply chain management measurement and its influence on operational performance. Journal of Operations and Supply Chain Management, 4(2), 56-70.

Ferdinand, A. (2006). Metode Penelitian Manajemen Pedoman Penelitian untuk Penulisan Skripsi Tesis dan disertai Ilmu Manajemen, Semarang: Universitas Diponegoro.

Fredberg, T., Beer, M., Eisenstat, R. A., Foote, N., \& Norrgren, F. (2008). Embracing commitment and performance: CEOs and practices used to manage paradox. Available at SSRN 1086443.

Gallato, C. G., Rashid, S., Warokka, A., Reamillo, K. A. G., \& Abdullah, H. H. (2012). Fostering niches among SMEs in Malaysia through organizational commitment, leadership, organizational culture and job satisfaction. Journal of Innovation Management in Small \& Medium Enterprises, 2012(2012), 1-12.

Ghozali, I. (2016). Ghozali, Imam.(2016). Aplikasi Analisis Multivariate dengan Program IBM SPSS 23. Semarang: BPFE Universitas Diponegoro. IOSR Journal of Economics and Finance. https://doi. org/https://doi. org/10.3929/ethz-b000238666

Gimenez, C., Van Der Vaart, T., \& Van Donk, D. P. (2012). Supply chain integration and performance: the moderating effect of supply complexity. International Journal of Operations \& Production Management, 32(5).

Griffin, E. M. (2006). A first look at communication theory. McGraw-hill.

Guney, Y., Li, L., \& Fairchild, R. (2011). The relationship between product market competition and capital structure in Chinese listed firms. International Review of Financial Analysis, 20(1), 41-51.

Hair Jr, J. F., Black, W. C., Babin, B. J., Anderson, R. E., \& Tatham, R. L. (2010). SEM: An introduction. Multivariate data analysis: A Global Perspective, 5(6), 629-686.

He, Y., Lai, K. K., Sun, H., \& Chen, Y. (2014). The impact of supplier integration on customer integration and new product performance: The mediating role of manufacturing flexibility under trust theory. International Journal of Production Economics, 147, 260-270.

Heizer, J., \& Render, B. (2013). Operations management: sustainability and supply chain management. Pearson Higher Ed. 
Indrajit, R. E., \& Djokopranoto, R. (2002). Konsep Manajemen Supply Chain: Cara Baru Memendang Mata Rantai Penyediaan Barang.

Indriantoro, N., \& Supomo, B. (2002). Metodologi penelitian bisnis: untuk akuntansi \& manajemen.

Johlke, M. C., \& Duhan, D. F. (2001). Testing competing models of sales force communication. Journal of Personal Selling \& Sales Management, 21(4), 265-277.

Karimi, E., \& Rafiee, M. (2014). Analyzing the impact of supply chain management practices on organizational performance through competitive priorities (case study: Iran pumps company). International Journal of Academic Research in Accounting, Finance and Management Sciences, 4(1), 1-15.

Khan, S. K., \& Rashid, M. Z. A. (2012). The Mediating Effect of Organizational Commitment in the Organizational Culture, Leadership and Organizational Justice Relationship with Organizational Citizenship Behavior: A Study of Academicians in Private Higher Learning Institutions in Malaysia. International Journal of Business and Social Science, 3(8).

Liew, C. B. A. (2008). Strategic integration of knowledge management and customer relationship management. Journal of Knowledge Management, 12(4).

Lu, D. (2011). Fundamentals of supply chain management. Bookboon.

Marhamati, A., Azizi, I., \& Marhamati, A. (2017). Impact of supply chain management on firm performance through T-JIT: Shiraz industrial estate. Journal of Business Studies Quarterly, 8(4).

Mas'ud, F. (2004). Survai Diagnosis Organisasi: Konsep dan aplikasi. Semarang: Universitas Diponegoro.'

Matin, H. Z., Jandaghi, G., Karimi, F. H., \& Hamidizadeh, A. (2010). Relationship between interpersonal communication skills and organizational commitment (Case Study: Jahad Keshavarzi and University of Qom, Iran). European Journal of Social Sciences, 13(3), 387-398.

Miller, K. (2009). Organizational communication: Approaches and processes 4th ed. Wadsworth Cengange Learning, Boston.

Modaff, D. P., Butler, J. A., \& DeWine, S. A. (2016). Organizational communication: Foundations, challenges, and misunderstandings. Pearson.

Mohr, J. J., Fisher, R. J., \& Nevin, J. R. (1996). Collaborative communication in interfirm relationships: moderating effects of integration and control. Journal of Marketing, 60(3), 103-115.

Morgan, R. M., \& Hunt, S. D. (1994). The commitment-trust theory of relationship marketing. Journal of Marketing, 58(3), 20-38.

Nawab, S., \& Bhatti, K. K. (2011). Influence of employee compensation on organizational commitment and job satisfaction: A case study of educational sector of Pakistan. International Journal of Business and Social Science, 2(8).

Neutzling, D. M., Land, A., Seuring, S., \& do Nascimento, L. F. M. (2018). Linking sustainability-oriented innovation to supply chain relationship integration. Journal of Cleaner Production, 172, 3448-3458.

Papa, M. J., Daniels, T. D., \& Spiker, B. K. (2007). Organizational communication: Perspectives and trends. Sage.

Plenert, G. J. (2014). Supply chain optimization through segmentation and analytics. Crc Press.

Pujawan, I. N. \& Mahendrawathi. (2010). Supply chain management. Kedua. Surabaya: Guna Widya.

Shiraz, M. A. E., \& Ramezani, E. (2014). Impact of Supply Chain Management Strategies on Competitive Advantage in Manufacturing Companies of Khuzestan Provinc. Singaporean Journal of Business, Economics and Management Studies, 51(1448), 1-6.

Stadtler, H., Stadtler, H., Kilger, C., Kilger, C., Meyr, H., \& Meyr, H. (2015). Supply chain management and advanced planning: concepts, models, software, and case studies. springer.

Sugiyono, D. R. (2002). Metode penelitian administrasi. Bandung: Alfabeta.

Thatte, A. A., Rao, S. S., \& Ragu-Nathan, T. S. (2013). Impact of SCM practices of a firm on supply chain responsiveness and competitive advantage of a firm. Journal of Applied Business Research (JABR), 29(2), 499-530.

Tungjitjarurn, W., Suthiwartnarueput, K., \& Pornchaiwiseskul, P. (2012). The Impact of supplier development on supplier performance: The role of buyer-supplier commitment, Thailand. European Journal of Business and Management, 4(16), 183-193.

Venus, K. (2014). Supply Chain Management_-Part of Strategic Management. Journal of Business and Economics, 5(7), 1052-1067.

Vogt, G. (2011). Supply Chain Coordination in Case of Asymmetric Information: Information Sharing and Contracting in a Just-in-Time environment (Vol. 650). Springer Science \& Business Media.

Yahaya, R., \& Ebrahim, F. (2016). Leadership styles and organizational commitment: literature review. Journal of Management Development, 35(2).

Zhu, Q., Krikke, H. R., \& Caniëls, M. C. (2014). Supply Chain Integration: Value Creation through Knowledge Management. In 26th NOFOMA annual conference (pp. 266-281). Copenhagen Business School.

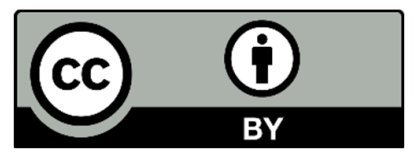

(C) 2021 by the authors; licensee Growing Science, Canada. This is an open access article distributed under the terms and conditions of the Creative Commons Attribution (CCBY) license (http://creativecommons.org/licenses/by/4.0/). 